This document is the Accepted Manuscript version of a Published Work that appeared in final form in:

Cazcarro I., López-Morales C.A., Duchin F. 2019. The global economic costs of substituting dietary protein from fish with meat, grains and legumes, and dairy. JOURNAL OF INDUSTRIAL ECOLOGY. 23. (5) 1159-1171. DOI (10.1111/jiec.12856). (C) 2019 by Yale University

This manuscript version is made available under the CC-BY-NC-ND 3.0 license http://creativecommons.org/licenses/bync-nd/3.0/

\title{
The Global Economic Costs of Substituting Dietary Protein from Fish with Meat, Grains and Legumes, and Dairy
}

Ignacio Cazcarro
a) Senior ARAID researcher. Agrifood Institute of Aragon (IA2)

Department of Economic Analysis. Faculty of Economics and Business Studies University of Zaragoza, Zaragoza, Spain

b) BC3-Basque Centre for Climate Change - Klima Aldaketa Ikergai

Edificio Sede 1, Planta $1^{\text {a }}$ | Parque Científico de UPV/EHU, 48940 Leioa, Bizkaia, Spain

Carlos A. López-Morales

Professor

Centro de Estudios Demográficos, Urbanos y Ambientales

El Colegio de México

Ciudad de México, México

Faye Duchin

Professor of Economics

Rensselaer Polytechnic Institute

Troy, NY USA

\begin{abstract}
This paper estimates the value of the ecosystem good comprised by fish in the human diet by calculating the costs to replace it by protein from meat, from grains and legumes, or from dairy products. We apply the World Trade Model, an input-output model of the interactions among major world regions based on comparative advantage, to analyze alternative scenarios about protein content and sources in global diets. We find that the substitution of fish by meat or dairy entails several trillion US dollars of additional costs annually, corresponding to increased use of pastureland, cropland, water, and other factors of production. The price of animal products increases steeply as higher-cost producers need to come online, yielding rents to owners of scarce resources. By contrast, the global economy adjusts at significantly lower costs to the substitution of fish by grains and legumes, but this dietary shift involves substantial modification in the mix of agricultural output and its geographic distribution. There have been few analytic studies able to associate costs and prices directly with specific combinations of dietary options. We provided a flexible economic framework for analyzing alternative scenarios about the present and future production of food. The focus on the provision of protein for the human diet, allowing for substitutions between land-based and aquatic sources, lays the groundwork for subsequent closer examinations of the potential future contribution of aquaculture and, in a yet broader framework, the impact of the coming generation of large dams on fish habitat and freshwater ecosystems more generally.
\end{abstract}




\section{The Global Economic Costs of Substituting Dietary Protein from Fish with Meat, Grains and Legumes, and Dairy}

\section{Introduction}

The intake of animal protein in human diets increased substantially over the course of the $20^{\text {th }}$ century. Between 1961 and 2014 the global average per capita consumption of meat and fish combined almost doubled from eleven to twenty grams per day, growing from eight to fifteen grams for meat and from three to five grams for fish (FAO 2016). Meat and fish represent today $45 \%$ and $17 \%$ of total intake of animal protein, respectively, although their contributions differ substantially by continent (Béné et al. 2015) (Figure 1). The factors driving the increase, mainly ease of trade in perishables, growing population, and greater affluence in developing countries (Porkka et al. 2013), are projected to remain important for decades to come as the nutritional content of diets in developing countries continues to improve. Since global population is expected to reach at least nine billion by 2050 with most of the increase in developing countries, the ability to keep up with food demand is a substantial concern. The problematic environmental impacts of global livestock production are evident and well documented, and the competition between conservation of natural vegetation for environmental sustainability and land clearance for food production will become more intense (Lambin and Meyfroidt 2011).

Insert Figure 1

As for fish in the diet, the future expansion of global production is also questionable. Global wild marine capture leveled off in the 1990s, mainly due to overexploitation or even collapse of some marine stocks (Figure 2). While inland wild capture more than doubled over the last three decades (Welcomme 2001 and FAO 2016), inland stocks are at risk from degradation of aquatic ecosystems due both to pollution and dam development, which is expected to further increase substantially over the rest of the century (Orr et al. 2012, Friend et al. 2009). As a result, it is unlikely that the contribution of inland capture to global production, currently at $4 \%$, will grow significantly, if at all, in decades to come. The notable area of expansion since the 1980s is aquaculture, an industrialized approach to fish production, practiced mainly in Asia for domestic consumption as well as export. Measured by weight, aquaculture's output was equivalent to $25 \%$ of marine wild capture in 1990 and by 2013 actually exceeded it (Figure 1 and Table S1 in the Supplementary Information, SI). Further expansion of aquaculture could make it feasible for fish production to keep up with global demand, but the prospects are highly problematic, with growing calls for regulation of environmental impacts associated with the sources of inputs and with marine pollution and health problems associated with dense stocking and highly concentrated wastes (Naylor et al. 2000 and 2009, Troell et al. 2014, Hamilton et al. 2016). 


\section{Insert Figure 2}

A growing literature identifies the many concerns surrounding the global provision of food, now and in the future, and suggests diverse strategies as potential solutions. While increase in agricultural production is widely recognized as necessary, a focus exists on promoting technologies with better environmental performance, sustainable use of land and water, a new look at small-scale production systems, and reduction of waste along the food supply chain. However, we observe that two important aspects do not receive adequate attention in that narrative. First, it is frequently recognized in the literature that the quantity and composition of diets, level of affluence, choices among technologies, availability of arable land and water, global trade in food, and food prices are highly inter-related in ways not adequately captured in existing analytic approaches. Second, but much less discussed, is that the unique role of fish in the human diet is scarcely examined in relation to challenges to fish stocks. If the critical conditions of the latter continue to deteriorate, and if the expansion of aquaculture proves to be problematic, then the challenges facing the global supply of food are compounded by the need to provide adequate supplies of protein in particular.

We respond to this assessment of the literature by proposing a framework that explicitly represents these interactions in terms of both their physical aspects and associated economic implications. We apply this framework to scenarios based on alternative sources of dietary protein to evaluate the importance of maintaining fish protein in the global supply of food. This paper estimates the global economic value of fish in the human diet, and that of the supporting ecosystem services. We investigate how the global economy could respond to the loss of fish in the human diet and at what additional cost. Calculations take account of the embodied resources and production processes for providing well-defined substitutes to fish protein, namely expanding the availability of protein from meat, from grains and legumes, or from dairy products.

We find that protein from dairy products represents the costliest substitute for fish protein, followed by protein from meat, with grains and legumes the option of lowest additional cost. All these options are costlier than protein from wild-caught fish, in which case nature provides the living space, the food input, and the waste disposal (Westhoek et al. 2011 and 2014, Reijnders and Soret 2003, Pimentel and Pimentel 2003). By contrast, the human activities for raising livestock call on a different mix of inputs in most parts of the world, predominantly land, feed, and water. We find that, relative to baseline conditions, the substitution of fish by dairy requires expansions of $29 \%, 25 \%$, and $13 \%$ in the use of cropland, pastureland, and water, respectively, while for the substitution by meat the increases are comparable at 26\%, 29\%, and $10 \%$, respectively. As a consequence, world prices for meat products increase substantially in both cases, and the prices of grains and other crops also rise. The substitution of fish by grains and legumes entails substantial increases in the use of cropland (26\%) and water (15\%) but only a 
123 negligible increase in pastureland, the main reason for the lower cost relative to the other options 124 analyzed.

126 The rest of the paper is organized as follows. Section 2 reviews key articles identifying the main 127 emerging challenges facing the global food system and some of the options for addressing them, 128 and it situates the present study with respect to this literature. Section 3 introduces the economic 129 model, the associated database, and the design of scenarios. Section 4 presents the numerical 130 results of the scenario analysis, and section 5 discusses them, offering conclusions and next 131 steps. The Supplementary Information (SI) describes the mathematical model, the relationship 132 between the material and economic relationships, and several tables of more detailed data than 133 what appears in the text. 


\section{Review of the literature}

The last decade has seen a substantial increase in the number of studies on the present and future adequacy of the global system of food supply. The main concern is environmental sustainability, and the overall conclusion is cautiously positive although substantial modifications of current production systems and consumer behavior are required. We organize the discussion around demand for food (in Section 2.1), production and technology (Section 2.2), and resource requirements (Section 2.3). We also review previous studies of the challenges facing the global food system (in Section 2.4). We conclude that the importance of fish is under-estimated in this literature, given the progressive deterioration of fish stocks. This literature stresses the lack of, and need for, analytic frameworks that reflect the web of interdependencies that characterize the global food system. In this paper we propose one such framework, which is used in the analyses reported below.

\subsection{Global demand for food, population, diets, and waste management}

Two widely cited studies by Alexandratos et al. (2006) and Alexandratos and Bruinsma (2012) estimate that global food supply in 2050 will need to increase by between $60-70 \%$ relative to 2005-07 levels under a business-as-usual (BAU) scenario. While output of all food products increases, the rates differ, from $45 \%$ for cereal grains, $75 \%$ for meat products, to $90 \%$ for oilseeds. Tilman et al. (2011) conclude that global crop production, including feed for livestock and aquaculture, needs to increase by $100-110 \%$ (relative to 2005) to meet demand in 2050; Fischer et al. (2014) estimate crop demand in 2050 at $60 \%$ higher than in 2010; Springer and Duchin (2013) estimate increases by 2050 for crops (up to 51\%), rainfed cereals (up to 96\%), irrigated cereals (up to $136 \%$ ), and livestock (up to 130\%), all relative to 2000, based on alternative assumptions regarding changes in diets and agricultural technologies. Bijl et al. (2017) estimate an increase in crop demand of $70 \%$ relative to 2010 under a BAU scenario, mainly composed of higher demand for feed crops required to increase caloric intake from animal products. Hubert et al. (2010) estimate increases of $56 \%$ for cereals, $41 \%$ of which to be utilized as feed, in the 2000-2050 period, and Valin et al. (2014) estimate an increase of 59\% to $98 \%$ for food demand, which turns out to be more sensitive to socioeconomic assumptions than to climatic variance. While the comparability of these estimates depends on various assumptions and scenarios, there is unanimous consensus on the main driving factors, population and affluence, and similar magnitudes for the required increases in food production.

The latest projection from the United Nations for population in 2050 is 9.7 billion, with $50 \%$ of the increment (over 2007) in Africa and another 40\% in Asia (United Nations 2017). The contribution of population growth to increased food demand is expected to diminish while per capita income continues to increase, especially in developing countries (Hertel 2015, Godfray 
and Garnett 2014, Bijl et al. 2017). Most people currently consume a largely plant-based diet, voluntarily or not. In developing countries this diet is largely involuntary due to limited availability of affordable animal-based foods. Many plants are low in protein content and lack one or more amino acids required for human nutrition. Consequently, protein deficiency is the most common form of global malnutrition, a situation from which about $10 \%$ of the world's population currently suffers (FAO, IFAD and WFD 2015). Increased affluence boosts food demand through modification of diets; a transition towards animal protein, particularly from land-based sources, is well underway in the developing world (Alexandratos and Bruinsma 2012; Godfray and Garnett 2014). If observed diet trends continue, the caloric content of the average global diet in 2050 would contain $23 \%$ more pork and poultry, $31 \%$ more meat, $58 \%$ more dairy and egg, and $82 \%$ more fish and seafood (Tilman and Clark 2014). This outcome, however, is unlikely, especially given the deteriorating state of fish stocks.

One approach to resolving the dilemma is waste management along the food supply chain (Foley et al. 2011; McKenzie and Williams 2015; Searchinger et al. 2014). Although the figures are subject to uncertainty (Parfitt et al. 2010), it has been estimated that about $24 \%$ of the caloric content (32\% by weight) of all food produced is lost: about $35 \%$ of the loss occurs at the consumption stage, while production and storage are responsible for a quarter each (Lipinski et al. 2013). A 50\% reduction in food loss and waste can provide substantial reductions in resource use by 2050 (14\% less cropland and $9 \%$ less pastureland; and $15 \%$ less water use and $23 \%$ less greenhouse gas emissions) and is regarded as a sine qua non condition for satisfying future food demand (Bajželj et al. 2014). While the potential of waste reduction in promoting food security by 2050 is significant, it may have a weaker impact than diet change: one study estimates that a $100 \%$ reduction in overall waste reduces food demand in 2050 by $10 \%$ relative to a BAU scenario, whereas global convergence to a low-meat diet reduces it by $41 \%$ (Bijl et al. 2017), a result that is consistent with Valin et al. (2014), which highlights the increasing importance of diet choices in determining the adequacy of the future food supply.

\subsection{Sustainable intensification of agriculture, yield gaps, and production systems}

The current system of food production could provide the volume and composition of food required by 2050 only by increasing the use of water and fertilizers to improve crop yields (Mueller et al. 2012; Grafton et al. 2015, Fischer et al. 2014). Such intensification, however, cannot extend the Green Revolution due to generalized soil degradation, water pollution, and biodiversity loss caused by impaired ecosystems and land conversion (Foley et al. 2011; Chartres and Noble 2015; Erisman et al. 2016).

Technological optimism based on $20^{\text {th }}$-century agricultural developments has eroded because a "biophysical plateau" limits potential yields to about $20 \%$ above the current average global level (Licker et al. 2010; Hertel 2015; Fischer et al. 2014; Ehrlich and Harte 2015a). The gap between 
potential and actual yields, however, remains substantial for many world regions, including Africa, much of Latin America, and Eastern Europe (Neumann et al. 2010). Closing this gap could substantially increase output: a worldwide $95 \%$ reduction could increase supply by $58 \%$ for selected crops (Foley et al. 2011). From a global perspective, selective increases in use of agricultural chemicals are found to be more important for closing the yield gap than extending irrigation, but the undesirable environmental implications of nutrient intensification can also be substantial (Licker et al. 2010; Mueller et al. 2012). Global investment in agricultural R\&D in developing countries has been increasing, mainly in China and India, with other regions, especially Africa, lagging (Beintema et al. 2012).

Increased food demand also has implications for the mix of production systems, e.g., large-scale monoculture or small-scale polyculture (Godfray and Garnett 2014). The dominance of monoculture, mainly in large-scale units in North America and Europe (FAO 2014), raises concerns about environmental vulnerability (Altieri et al. 2015; Tilman and Clark 2015). Smallscale agriculture is practiced mainly in Asia, Africa and Latin America on over 500 million family farms of less than two hectares, supporting the livelihoods for 1.5 billion people (Wolfenson 2013) and supplying about 20\% of total crops (Altieri 2009; FAO 2014). Several studies conclude that small-scale polyculture is more productive than large-scale monoculture in terms of total output, enabling provision of a more complete set of nutrients per unit of land (Altieri 2009; Zhang et al. 2014; Ebel et al. 2017; Pittelkow et al. 2015; Tscharntke et al. 2012). Higher genetic diversity in small-scale polyculture also contributes to resilient food production in a context of rapid environmental change (Altieri 2009, Altieri et al. 2015, Jacobsen et al. 2015, Bellon et al. 2018), and its role is considered as increasingly important for global food security (Altieri et al. 2012, and 2015, Hengstler 2015, Tscharntke et al. 2012 Erisman et al. 2016).

\subsection{Land and water use and the impacts of climate change}

Globally, 1.4 billion hectares of land are considered "prime" or "good" and could be brought into production to supplement the 1.6 billion hectares currently in use, according to Alexandratos and Bruinsma (2012). How many of these will actually become active depends on the balance between seeking higher yields vs. expansion to increase output. Estimates for future land expansions in the literature reflect a variety of assumptions. For instance, the satisfaction of future food demand in China alone could require expanding in-use agricultural land by 70 million hectares in Africa and Latin America (Yu et al. 2016). Another study estimates that global food demand will require about an additional 200-300 million hectares over the same period, also mainly in Africa (Schmitz et al. 2014). In the absence of technological improvements and of dietary moderation in developed countries, in-use land in 2050 could be $87 \%$ higher than in 2000, also mainly in Africa and Latin America, whereas the increase is kept to $46 \%$ under a combination of new technologies and diet moderation (Springer and Duchin 2013). 
Ecosystem degradation and biodiversity loss are intimately associated with land conversion for food production (Tilman and Clark 2015; Ehrlich and Harte 2015b; Godfray and Garnett 2014). A clear trade-off exists between food production and environmental protection (Godfray and Garnett 2014, Delzeit et al. 2017), and sustainability requires the establishment of conversion limits (Hertel 2015). Climate change can affect the geographical distribution of agricultural land, increasing endowments in higher latitudes and decreasing them in tropical regions (Juliá and Duchin 2007). Depending on climatic assumptions, satisfying food demand by the end of the century could require conversion of between 100 and 700 million hectares of forest into cropland and pastureland, mainly in Africa and in Latin America (Juliá and Duchin 2013). The prospects of land expansion for food production and the need for environmental conservation call for new approaches to agriculture that reconcile the adequacy of output, rural livelihoods, and conservation of biodiversity (Ehrlich and Harte 2015a, Tscharntke et al. 2012).

Since 1995 at least a third of the world's population lives under moderate to severe water stress, and the fraction is expected to increase under several climate change scenarios for 2025 (Vörösmarty et al. 2000), for 2050 (Gosling and Arnell 2016) and for the end of the century (Hanasaki et al. 2013). Irrigation is set to play a significant role in expanding food production by 2050 (Alexandros and Bruinsma 2012), and water withdrawals would need to rise by up to $83 \%$ relative to 2010 (Hanjra and Qureshi 2010), or 93\% relative to 2000 (Springer and Duchin 2013), in all cases well beyond the "safe operating space" of future water management (Grafton et al. 2015). Increased competition over water will reduce its availability for irrigation by 2050 (Strzepek and Boehlert 2010, Elliott et al. 2014). Given that $30 \%$ of 2010 withdrawals were already deemed unsustainable, and that the fraction could grow to $40 \%$ by end-of-century (Wada and Bierkens 2014), future water sustainability would require limiting both over-extraction of groundwater and diversion of surface water. Flood irrigation still dominates on at least $80 \%$ of the global irrigated area (FAO 2016): the adoption of more efficient irrigation technologies can reduce requirements per unit of food output (Jägermeyr et al. 2016). On the basis of these studies, technologies that conserve water need to be accorded a high priority.

\subsection{Empirical studies using the World Trade Model (WTM)}

Several studies regarding the future provision of food have been carried out using the WTM (Duchin, 2005a). Duchin (2005b) described a framework to integrate resource requirements and stocks into an input-output (IO) model of global food production, realized in the WTM. Juliá and Duchin (2007) conclude that shifts in comparative advantage in agricultural production would make it possible to satisfy 1990 levels of global food demand under climate change assumptions although at somewhat higher prices for food. In a follow-up study, (Juliá and Duchin, 2013) 
they conclude that future global food demand for 2100 will lead to significant increases in food prices as well as requiring further conversion of intact forests for agricultural uses.

Springer and Duchin (2014) specify explicit changes in diet, namely more animal products in developing regions offset by a reduced portion of calories from animal products in industrialized regions. They conclude that moderate improvements in agricultural productivity in developing regions, especially in Africa, could make it possible to satisfy global demand for food by midcentury, using resources sustainably and without sharp increases in food prices. This is achieved by a massive shift from developed to developing countries in food production and exports, in particular Sub-Saharan Africa. They find that environmental benefits from reducing animal products in the diet in rich countries offset only a small share of resource requirements for improving diets in the far more populous developing countries.

The present study builds on this body of work in several ways. It specifies potential changes in demand for food and uses the WTM to allow for choices among alternative technologies subject to factor constraints, with available land and water treated as factors of production. Dietary assumptions focus on the quantity and sources of protein, a critical aspect of food sufficiency that has not yet gotten adequate attention. The major sources of animal protein in the diet are meat and fish, and the study sets out to quantify the economic and environmental implications of diets leaning more heavily on one or the other, or on plant-based options.

\section{Modeling approach}

\subsection{The WTM with choice of technologies and database}

The study implements a version of the WTM that incorporates the logic of the Rectangular Choice of Technologies (RCOT) model for each region (Duchin and Levine, 2011 and 2012). The resulting WTM/RCOT model, which is provided in the SI, consists of two interrelated components. The so-called primal model assigns production to regions according to comparative advantages generalized to the case of $m$ regions, $n$ sectors, and $k$ factors of production. The complementary dual model determines commodity prices of traded products and scarcity rents on fully utilized resources and other factors of production. The database includes two rectangular matrices of parameters, $\mathbf{A}_{i}^{*}$ and $\mathbf{F}_{i}^{*}$, containing requirements for intermediate inputs and for factors of production, respectively, for each region $i$. Table $\mathrm{S} 2$ in the SI describes the exogenous and endogenous variables.

In addition to labor and built capital, land as factors of production, the database also distinguishes as factors pastureland, cropland, surface water and liquid groundwater, and fish. The Baseline scenario uses the GTAP database for 2007 (Narayanan, 2012 and 2015), supplemented by a variety of other sources described in the SI. We aggregate the GTAP database 
to 48 sectors (Table S3 in the SI), of which twelve are agricultural: eight crops and four types of livestock. We work with 14 regions, distinguishing those with large economies, populations, land areas, and water withdrawals, and with diverse climates (Table S4 of the SI), and we construct for each region a vector of endowments of factors of production, mostly in physical units (Table S6 for the regional detail for cropland and pastureland and for fish, along with data sources). The fishery sector has two technology options, wild capture and aquacultural production; and livestock production may utilize pastured or confined technologies (data sources in Table S5 in the SI). Finally, Baseline data for final demand for fresh fish, processed fish, fresh meat, and processed meat are shown in Table S7 in the SI, while assumptions for changes in final demand under alternative scenarios are given in Table S8.

\subsection{Scenarios}

We first construct a Baseline Scenario, S0, to represent the global economy in the base year (2007). Six experimental scenarios represent alternative dietary sources of protein. Scenario S1A has four variants, under which $25 \%, 50 \%, 75 \%$, or $100 \%$ of protein from fish is obtained instead from meat. Under Scenario S1B, fish protein is substituted by plant-based sources, and under S1C, the source of the replacement is from dairy products. Under Scenario S2, at the other extreme, fish and fish products replace all meat and meat products in the diet. These assumptions are implemented by modifying both intermediate and final demand for different sources of protein.

From the point of view of human health, the substitution between meat and fish is best represented in terms of a unit measuring nutritive content. However, we have found it convenient to use money values to measure these products in our database, as it is the unit used in our data sources, and we consider the choice a reasonable approximation for the following reasons. Most meats and fish are roughly comparable in grams of protein per unit of mass (about six to seven grams per ounce) and in nutritional value more generally (Gebhardt and Thomas 2002, Drewnowski 2010, Dolson 2015). Furthermore, the price per $\mathrm{kg}$ of most varieties of fish and of the most widely consumed meats, namely poultry and pork, are roughly comparable (OECD-FAO 2014). For a more detailed analysis, these sectors could be disaggregated to distinguish the major sources of meat and fish protein by mass and take account of the mass equivalents for specific nutrients, in particular protein and fats, as done for other substitutions (FAO 2017). The Supplementary File addresses how these equivalences are obtained for this implementation.

When all animal protein is from livestock under Scenario S1A, we reduce intermediate and consumer demand for fresh fish and processed fish (two rows in $\mathbf{A}_{i}^{*}$, and two components of $\mathbf{y}_{i}$, respectively) to zero and add these quantities to the two rows of intermediate demand and the two components of final demand for livestock and processed meat, respectively; this 
manipulation effectively increases global demand for livestock by $47 \%$ and for processed meat by $75 \%$ when compared to the Baseline Scenario, S0 (Table S8 in the SI for the regional breakdown of these changes). To make a modest but reasonable allowance for expanded livestock production under S1A, we increase the pastureland endowment for each region over the Baseline Scenario by $10 \%$ of region-specific endowments of unmanaged land, savannah and grasslands deemed available for grazing animals. Scenario S2 eliminates all intermediate demand and consumer demand for livestock and meat products and augments demand for fish by the corresponding amounts. The purpose of this scenario is to evaluate the rates of expansion of fish stocks that would be needed to make this possible.

We next implement variants of Scenario S1A where only $25 \%, 50 \%$ and $75 \%$ of fish in the diet, respectively, is substituted by livestock. Scenario S1B substitutes fish by grains and legumes (including paddy rice, wheat, beans, cereal grains, nuts and seeds, and vegetables) and a wide variety processed foods. Scenario S1C substitutes fish and processed fish by dairy products. Table 1 summarizes the assumptions behind these scenarios.

Insert Table 1

\section{Results}

\subsection{Changes in global output of livestock, processed meat, and grains}

The first set of results shows that the substitution of all fish by meat (Scenario S1A), by grains and legumes (Scenario S1B), and by dairy products (S1C) all have feasible solutions. This means that the portion of dietary protein provided by fish in the base year could in principle be obtained from livestock, dairy products, or grains and legumes through fuller utilization of available resources and shifts in the international division of labor. In principle, this result suggests that if fish stocks for wild capture continue to deteriorate, it is possible to supply nutritionally adequate substitutes for the global economy. By contrast, the substitution of meat by fish (under Scenario S2) does not have a feasible solution. Repeated runs of S2 show that the substitution of dietary protein from meat by fish would require maintaining global stocks of wild fish at about double their current average levels or increasing aquaculture nearly threefold. These conditions are unlikely for wild capture, and we leave the exploration of the limits for aquaculture to another study. For present purposes we regard S2 as infeasible and focus on a closer examination of the results of Scenarios S1A, S1B, and S1C.

When all fish is replaced by meat under Scenario S1A, the processed meat sector increases its output by $75 \%$ relative to the Baseline Scenario, almost double the rate of increase required of the livestock sector (39\%). Global grain production increases significantly to satisfy higher input 
demand from the meat sectors. However, global grain production increases by only $10 \%$ because meat production still depends mainly on grazing and is not now the major use of grain (Tables S9 and S10 in the SI show the regional breakdown of the global figures). When legumes and grains provide the protein otherwise obtained from fish (Scenario S1B), the increases in output of meat-related sectors are less dramatic than under Scenario S1A, while global grain output increases by $8 \%$, explained by direct consumption on final demand rather than indirect use as an input for production. (Table S11 shows the regional breakdown of the global figures). Under

Scenario S1C, where dairy products substitute for fish, the global outputs of the livestock sector and the associated processed products increase by $26 \%$ and $53 \%$ relative to the Baseline, driven mainly by inter-industry demand from the dairy sectors (Table S11 in the SI shows the regional breakdown for these global figures). Under this scenario, the grain global output increases by $\underline{5 \%}$, mainly to satisfy intermediate requirements from the dairy, livestock, and the processed meat sectors.

Insert Table 2

\subsection{Changes in the use of water, pasture land and cropland}

Scenarios involving substitution of fish by meat (S1A) or by dairy (S1C) require substantially expanded use of pastureland ( $29 \%$ and $25 \%$ relative to S0, respectively), as well as of cropland (26\% and $29 \%$ ) and water (10\% and 13\%). However, the percentage increase in pastureland under S1A is smaller than the increase in livestock production (Table 3) because a portion of the increase in the latter is provided by regions dominated by confined animal husbandry. Similarly, while the global use of cropland is $26 \%$ higher under S1A relative to S0, global water withdrawals increase by only $10 \%$. This is explained by the variability in water intensity of different livestock systems and by an observed shift under S1A from irrigated to rainfed agriculture. (Table S12 in the SI shows the regional breakdown of resource use under Scenario $\mathrm{S} 1)$.

\section{Insert Table 3}

Changes in resource use under Scenarios S1A are also shown in Table 3. In the case of water use, a $25 \%$ substitution of fish by meat leads to a $6 \%$ increase in water withdrawals, rising to $10 \%$ under the $100 \%$ substitution. Increases in the use of pastureland and cropland are also low - until 75\% of fish is substituted by livestock. (Table S13 in the SI shows the regional breakdown of the S1A scenario results.) By contrast, the substitution by grains and legumes under S1B requires a $26 \%$ increase in the use of cropland and a $15 \%$ increase in water withdrawals but negligible change in the use of pastureland (Table S14 in the SI shows the regional breakdown). The results suggest that the global economy would require a more intensive use of these categories of land and water if fish stocks were lost as protein sources for 
the human diet. The projections reported in the literature (Section 2) for resource requirements to satisfy future demand for food are systematically under-estimated if land-based protein sources are needed to compensate for the potential loss of fish as a substantial source of animal protein.

\subsection{Impacts on global economic costs and on prices}

Global money incomes must be adequate to cover all outlays for purchases, and this is assured in our modeling framework (shown as equation (9) in the SI), which reconciles the primal and dual models. The difference in total factor costs associated with a particular scenario, relative to the Baseline scenario, reflects changes in the quantities of factors employed and changes in their unit prices. Substitution by dairy products (scenario S1C) increases global economic costs by about $\$ 3$ trillion a year, followed by the substitution by meat products (S1B), which augments costs by $\$ 2.8$ trillion. The increase for the substitution of fish by legumes and grains (S1C), at $\$ 1.8$ trillion, is the least costly of the analyzed options (Figure 3). In all cases, price increases reflect the need for higher-cost producers to supplement the output capacities of the lower-cost producers, resulting in greater factor use and non-zero rents on those resources that have become scarce.

Price increases for individual products are shown in Table 4 for all scenarios as percentage changes relative to the Baseline Scenario. With substitution of all fish by meat (Scenario S1A), the prices for livestock related products increase substantially, including for processed meat $(82 \%)$, for livestock $(72 \%)$, and for other animal products $(69 \%)$. There is also a small increase in grain prices $(10 \%)$. Most of the price increases occur only after $75 \%$ of fish has been replaced in the diet, consistent with the increases in resource use reported earlier and the behavior shown in Figure 3. These results suggest the potential to increase meat output substantially before needing to supplement output furnished by the very high-cost producers. As animal production increasingly moves from outdoor grazing to confined environments, the stock of built capital for this sector could replace pastureland as a potential constraint on output expansion. We examine the sensitivity of our results if built capital for industrial husbandry is increased and find that it would be adopted (because of lower cost) in more regions. However, a fuller cost comparison regarding confined livestock production would require accounting for the costs of assuring safe handling of the concentrated wastes, which is beyond the scope of this paper.

\section{Insert Table 4}

\section{Discussion and concluding remarks}

Is the global system of food production capable of generating a nutritionally adequate diet for an expanding population over the next several decades? This question receives a cautiously positive answer in the scientific literature reviewed in Section 2, with areas of concern including resource scarcity, environmental degradation, and diminished opportunities for improving yields. 
Strategies for facing these challenges that are discussed in the literature include expansion onto additional land, technological change, reduction of food waste, and adoption of less resourceintensive diets. However, these strategies need to be revisited taking nutritional adequacy into account. We attempt to do that here by focusing on the contribution of fish to the human diet and its dependence on assuring the integrity of fish stocks. Overfishing and pollution systematically reduce wild catch in both marine and freshwater environments, and current prospects for mega-sized dams portend the further degradation of fish habitat, especially in developing countries. Furthermore, while the output of aquaculture grew substantially in recent decades, environmental concerns make its continued expansion problematic. If the conditions for fish production continue to deteriorate, then the challenges facing the global food system will be harder still.

The literature concerned with assuring food security calls for systemic approaches to analytical frameworks that can link food demand, technological alternatives, resource endowments, and comparative regional advantages explicitly into account at the global level. We propose and apply such a framework and formulate a set of scenarios to examine more closely the contribution of fish to the human diet. We estimate the money value of preserving fish in the diet by evaluating the physical implications and economic costs of substituting fish protein by alternative protein sources, namely meat, grains and legumes, or dairy products. We use an input-output model of the global economy formulated as a constrained optimization problem that allows for choices among alternative production options within and among regions based on the logic of comparative advantage. The model is applied to a database incorporating substantial detail about the region-specific production of fish and meat products, crop agriculture, and regional factor endowments and factor prices.

We find that the world economy can adjust to the loss of fish in the diet at substantially lower cost by increased reliance on protein from grains and legumes than from meat or from dairy products. If all fish were substituted by meat, we estimate the annual money cost of the additional factors of production, including rents on scarce resources, at close to $\$ 2.8$ trillion a year. The need to engage higher-cost producers results in substantial increases in the prices of foods related directly and indirectly to meat production, with rents received by those with property rights to resources that become scarce. Additional economic costs incurred in the substitution of fish by dairy amount to about $\$ 3$ trillion a year, with even higher increases in the prices of livestock-related products. These two scenarios require expansion of meat-related sectors, but the regional distribution of related outputs changes only slightly. Most of the increase in livestock production and processed meat output is located in Brazil, Russia, the United States, and the European Union, sometimes joined by other Latin American countries. By contrast, increments in grain output are concentrated in Southeast Asia, the European Union and, to a lesser extent, in India (see Tables S9-S14 in the SI). 
The substitution by grains and legumes, while requiring a substantial shift in the relative importance of crop production and animal husbandry, results in lower additional economic costs of $\$ 1.8$ trillion a year, making it the least costly of the options considered. Lower demand for land and water for livestock production (relative to the other scenarios) leads to a shift in the geographical distribution of grain output, mainly in the European Union, Canada, and North Africa, whereas Southeast Asia experiences a substantial decrease in its grain output. The substitution by grains and legumes requires greater increases in water withdrawals and expansion of cropland but much lower use of pastureland (compared to the substitution by meat or dairy), the main reason for its lower cost.

The modeling framework employed in this study makes it possible to capture interdependencies among changes in the composition food demand, choices among production technologies, and constraints on resource availability. One refinement for future work is to improve our assumptions regarding the nutrient equivalence of different protein sources by measuring dietary components in mass and nutrient content and take both into account in different contexts. That would contribute to the ongoing effort to measure products and factors in input-output databases in appropriate physical units. In particular, the aggregation of sectoral data in the GTAP database leads us to recognize the importance of having more detailed representations of production technologies and inter-industry linkages informed by researchers of the sectors involved. Second, a quantitative description is needed for the input structures for confined animal production for fish (aquaculture), poultry, livestock, and other animals, preferably also in collaboration with researchers with expertise on this subject. These sectors require closer examination as it appears likely, according to our results, that they can be increasingly cost-competitive as alternative technologies to those facing tighter constraints on resource availability. The production technologies need to take account of feed requirements, health of confined animals, and safe handling of animal wastes, preferably their recovery for fertilizer or fuel.

In future work we expect to introduce economic dynamics into the WTM/RCOT modeling framework for closer examination of alternative ways of providing for infrastructure requirements. The functioning of freshwater fisheries is now challenged by a wave of dam construction throughout the developing world, including the mega-scale Grand Inga on the Congo River, numerous dams planned for the Blue Nile in Ethiopia and the Mekong in Southeast Asia, and the Belo Monte on the Amazon River. While these offer advantages for development, they are disruptive of the human communities and the ecosystems they affect. Options for the provision of water, food, electric power, and transportation are highly interconnected. The framework for scenario analysis utilized in this study can be valuable in the context of crossdisciplinary collaboration to examine the trade-offs among different approaches to achieving economic development that is environmentally sustainable.

\section{Acknowledgements}


574 This work was supported by US National Science Foundation CNH grant \#1115025, "Impacts of 575 Global Change Scenarios on Ecosystem Services from the World's Rivers.” The authors

576 acknowledge input from the project team and from previous model code created by Nathaniel

577 Springer and Stephen Levine. 


\section{References}

Alexandratos, N., Bruinsma, J., Bödeker, G., Schmidhuber, J., Broca, S., Shetty, P., \& Ottaviani, M. G. (2006). World agriculture: Towards 2030/2050. Interim report. Prospects for food, nutrition, agriculture and major commodity groups. Global Perspective Studies Unit, Food and Agriculture Organization of the United Nations, Rome

Alexandratos, N. and J. Bruinsma. 2012. World agriculture towards 2030/2050: the 2012 revision. ESA Working paper No. 12-03. Rome, FAO.

Altieri, M. A. (2009). Agroecology, small farms, and food sovereignty. Monthly review, 61(3), 102.

Altieri, M. A., Funes-Monzote, F. R., \& Petersen, P. (2012). Agroecologically efficient agricultural systems for smallholder farmers: contributions to food sovereignty. Agronomy for Sustainable Development, 32(1), 1-13.

Altieri, M. A., Nicholls, C. I., Henao, A., \& Lana, M. A. (2015). Agroecology and the design of climate change-resilient farming systems. Agronomy for Sustainable Development, 35(3), 869-890.

Bajželj, B., Richards, K. S., Allwood, J. M., Smith, P., Dennis, J. S., Curmi, E., \& Gilligan, C. A. (2014). Importance of food-demand management for climate mitigation. Nature Climate Change, 4(10), 924-929.

Beintema, N., Stads, G. J., Fuglie, K. O., \& Heisey, P. W. (2012). ASTI global assessment of agricultural $R \& D$ spending: developing countries accelerate investment. International Food Policy Research Institute.

Bellon, M. R., Mastretta-Yanes, A., Ponce-Mendoza, A., Ortiz-Santamaría, D., Oliveros-Galindo, O., Perales, H., ... \& Sarukhán, J. (2018). Evolutionary and food supply implications of ongoing maize domestication by Mexican campesinos. Proc. R. Soc. B, 285(1885), 20181049.

Béné, C., Barange, M., Subasinghe, R., Pinstrup-Andersen, P., Merino, G., Hemre, G. I., \& Williams, M. (2015). Feeding 9 billion by 2050-Putting fish back on the menu. Food Security, 7(2), 261-274.

Bijl, D. L., Bogaart, P. W., Dekker, S. C., Stehfest, E., de Vries, B. J., \& van Vuuren, D. P. (2017). A physically-based model of long-term food demand. Global Environmental Change, 45, 47-62.

Chartres, C. J., \& Noble, A. (2015). Sustainable intensification: overcoming land and water constraints on food production. Food security, 7(2), 235-245.

Delzeit, R., Zabel, F., Meyer, C., \& Václavík, T. (2017). Addressing future trade-offs between biodiversity and cropland expansion to improve food security. Regional Environmental Change, 17(5), 1429-1441.

Dolson, L. (2015) List of High-Protein Foods and Amount of Protein in Each Foods High in Protein, http://lowcarbdiets.about.com/od/whattoeat/a/highproteinfood.htm, last accessed March 10, 2016.

Drewnowski, A. (2010) The cost of US foods as related to their nutritive value, The American Journal of Clinical Nutrition 92(5): 1181-1188. 
Duchin, F. (2005a) A world trade model based on comparative advantage with $m$ regions, $n$ goods, and $k$ factors. Economic Systems Research 17, 141-162.

Duchin, F. (2005b) Sustainable consumption of food - A framework for analyzing scenarios about changes in diets. Journal of Industrial Ecology 9, 99-114. Reprinted in J. Martinez-Allier and I. Ropke, Eds., 2008, Recent Developments in Ecological Economics, Cheltenham: Edward Elgar Publishing Ltd.

Duchin, F. and S. H. Levine, 2011. Sectors May Use Multiple Technologies Simultaneously: The Rectangular Choice-of-Technology Model with Binding Factor Constraints, Economic Systems Research, 23(3): 281-302 (September).

Duchin, F. and S. Levine, 2012. The Rectangular Sector-by-Technology Model: Not Every Economy Produces Every Product and Some Products May Rely on Several Technologies Simultaneously, Journal of Economic Structures, 1(3).

Ebel, R., Cárdenas, J. G. P., Miranda, F. S., \& González, J. C. (2017). Manejo orgánico de la milpa: rendimiento de maíz, frijol y calabaza en monocultivo y policultivo. Tierra Latinoamericana, 35(2), 149160.

Ehrlich, P. R., \& Harte, J. (2015a). Food security requires a new revolution. International Journal of Environmental Studies, 72(6), 908-920.

Ehrlich, P. R., \& Harte, J. (2015b). Opinion: To feed the world in 2050 will require a global revolution. Proceedings of the National Academy of Sciences, 112(48), 14743-14744.

Elliott, J., Deryng, D., Müller, C., Frieler, K., Konzmann, M., Gerten, D., ... \& Eisner, S. (2014).

Constraints and potentials of future irrigation water availability on agricultural production under climate change. Proceedings of the National Academy of Sciences, 111(9), 3239-3244.

Erisman, J. W., van Eekeren, N., de Wit, J., Koopmans, C., Cuijpers, W., Oerlemans, N., \& Koks, B. J. (2016). Agriculture and biodiversity: a better balance benefits both. AIMS Agriculture and Food, 1(2), 157-174.

FAO (2014) The State of Food and Agriculture. Innovation in Family Farming. Rome: Food and Agriculture Organization.

FAO (2016) The State of World Fisheries and Aquaculture 2016. Rome: Food and Agriculture Organization. Last accessed: June 2, 2018.

FAO (2017) Food Balance Sheets (FBS). Nutritive Factors. Production. . Rome: Food and Agriculture Organization.

FAO, IFAD and WFP. 2015. The State of Food Insecurity in the World 2015. Meeting the 2015 international hunger targets: taking stock of uneven progress. Rome, FAO.

Fischer, R. A., Byerlee, D., \& Edmeades, G. (2014). Crop yields and global food security: will yield increase continue to feed the world? ACIAR Monograph No. 158. Australian Centre for International Agricultural Research: Canberra. 
Foley, J. A., Ramankutty, N., Brauman, K. A., Cassidy, E. S., Gerber, J. S., Johnston, M., ... \& Balzer, C. (2011). Solutions for a cultivated planet. Nature, 478(7369), 337-342.

Friend, R., R. Arthur, M. Keskinen (2009). Songs of the doomed: The continuing neglect of capture fisheries in hydropower development in the Mekong, in F. Molle, T. Foran, M. Käkönen (Eds.), Contested waterscapes in the Mekong Region: Hydropower, Livelihoods, and Governance, London: Earthscan.

Gebhardt, S.E. and R.G. Thomas. (2002) Nutritive Value of Foods, Agricultural Research Service, U.S. Department of Agriculture, Home and Garden Bulletin \#72.

Godfray, H. C. J., \& Garnett, T. (2014). Food security and sustainable intensification. Phil. Trans. R. Soc. $B, 369(1639), 20120273$.

Gosling, S. N., \& Arnell, N. W. (2016). A global assessment of the impact of climate change on water scarcity. Climatic Change, 134(3), 371-385.

Grafton, R. Q., Williams, J., \& Jiang, Q. (2015). Food and water gaps to 2050: preliminary results from the global food and water system (GFWS) platform. Food Security, 7(2), 209-220.

Hamilton, H. A., Brod, E., Hanserud, O. S., Gracey, E. O., Vestrum, M. I., Bøen, A., ... \& Brattebø, H. (2016). Investigating Cross-Sectoral Synergies through Integrated Aquaculture, Fisheries, and Agriculture Phosphorus Assessments: A Case Study of Norway. Journal of Industrial Ecology, 20(4), 867-881.

Hanasaki, N., Fujimori, S., Yamamoto, T., Yoshikawa, S., Masaki, Y., Hijioka, Y., ... \& Kanae, S. (2013). A global water scarcity assessment under shared socio-economic pathways. Hydrology and Earth System Sciences, 17(7), 2393.

Hanjra, M. A., \& Qureshi, M. E. (2010). Global water crisis and future food security in an era of climate change. Food Policy, 35(5), 365-377.

Hengstler, Joseph Allen, "Agriculture and sustainable development: The role of small scale agriculture in obtaining food security" (2015). Global Affairs. 26.

Hertel, T. W. (2015) The challenges of sustainably feeding a growing planet. Food Security, 7(2), 185198.

Hubert, B., Rosegrant, M., Van Boekel, M. A., \& Ortiz, R. (2010). The future of food: scenarios for 2050. Crop Science, 50 (Supplement_1), S33-S50.

Jacobsen, S. E., Sørensen, M., Pedersen, S. M., \& Weiner, J. (2015). Using our agrobiodiversity: plantbased solutions to feed the world. Agronomy for sustainable development, 35(4), 0.

Jägermeyr, J., Gerten, D., Schaphoff, S., Heinke, J., Lucht, W., \& Rockström, J. (2016). Integrated crop water management might sustainably halve the global food gap. Environmental Research Letters, 11(2), 025002 . 
Juliá, R., Duchin, F. (2007) World trade as the adjustment mechanism of agriculture to climate change. Climatic Change 82, 393-409.

Julia, R. and F. Duchin, 2013. Population Growth and Climate Change: Implications for Forestland Conversion and Global Food Prices, Sustainability, 5(12): 5442-5459 (open access).

Lambin, E. F., \& Meyfroidt, P. (2011). Global land use change, economic globalization, and the looming land scarcity. Proceedings of the National Academy of Sciences, 108(9), 3465-3472.

Licker, R., Johnston, M., Foley, J. A., Barford, C., Kucharik, C. J., Monfreda, C., \& Ramankutty, N. (2010). Mind the gap: how do climate and agricultural management explain the 'yield gap' of croplands around the world?. Global ecology and biogeography, 19(6), 769-782.

Lipinski, B., Hanson, C., Lomax, J., Kitinoja, L., Waite, R., \& Searchinger, T. (2013). Installment 2 of "Creating a Sustainable Food Future" Reducing Food Loss and Waste. World Resources Institute, United Nations Environment Programme: Washington, DC. http://www. wri. org/sites/default/files/reducing_food_loss_and_waste. pdf(accessed on 10/20/2015).

McKenzie, F. C., \& Williams, J. (2015). Sustainable food production: constraints, challenges and choices by 2050. Food Security, 7(2), 221-233.

Mueller, N. D., Gerber, J. S., Johnston, M., Ray, D. K., Ramankutty, N., \& Foley, J. A. (2012). Closing yield gaps through nutrient and water management. Nature, 490(7419), 254.

Narayanan, G.B., Aguiar, A. and McDougall, R. (2012) Global Trade, Assistance, and Production: The GTAP 8 Data Base, Center for Global Trade Analysis. Purdue University.

Narayanan, G., Badri, A.A., McDougall, R. (2015). Global Trade, Assistance, and Production: The GTAP 9 Data Base, Center for Global Trade Analysis. Purdue University.

Naylor, R.L., Goldburg, R.J., Primavera, J.H., Kautsky, N., Beveridge, M.C.M., Clay, J., Folke, C., Lubchenco, J., Mooney, H., Troell, M. (2000) Effect of aquaculture on world fish supplies. Nature 405, 1017-1024.

OECD-FAO (2014), Statistical Annex. OECD-FAO Agricultural Outlook. http://www.keepeek.com/Digital-Asset-Management/oecd/agriculture-and-food/oecd-fao-agriculturaloutlook-2014/statistical-annex agr outlook-2014-16-en\#page54, last accessed November 16, 2018, DOI:10.1787/agr_outlook-2014-16-en.

Orr, S., Pittock, J., Chapagain, A., Dumaresq, D. (2012) Dams on the Mekong River: Lost fish protein and the implications for land and water resources. Global Environmental Change 22, 925-932.

Parfitt, J., Barthel, M., \& Macnaughton, S. (2010). Food waste within food supply chains: quantification and potential for change to 2050. Philosophical Transactions of the Royal Society of London B: Biological Sciences, 365(1554), 3065-3081.

Pimentel, D., \& Pimentel, M. (2003). Sustainability of meat-based and plant-based diets and the environment. The American journal of clinical nutrition, 78(3), 660S-663S. 
Pittelkow, C. M., Liang, X., Linquist, B. A., Van Groenigen, K. J., Lee, J., Lundy, M. E., ... \& van Kessel, C. (2015). Productivity limits and potentials of the principles of conservation agriculture. Nature, 517(7534), 365

Porkka, M., Kummu, M., Siebert, S., \& Varis, O. (2013). From food insufficiency towards trade dependency: a historical analysis of global food availability. PloS one, 8(12), e82714.

Reijnders, L., \& Soret, S. (2003). Quantification of the environmental impact of different dietary protein choices. The American Journal of Clinical Nutrition, 78(3), 664S-668S.

Schmitz, C., van Meijl, H., Kyle, P., Nelson, G. C., Fujimori, S., Gurgel, A., ... \& Sands, R. (2014). Landuse change trajectories up to 2050: insights from a global agro-economic model comparison. Agricultural Economics, 45(1), 69-84.

Searchinger, T., Hanson, C., Ranganathan, J., Lipinski, B., Waite, R., Winterbottom, R., ... \& Dumas, P. (2014). Creating a sustainable food future. A menu of solutions to sustainably feed more than 9 billion people by 2050. World resources report 2013-14: interim findings.

Springer, N. and F. Duchin (2014) Feeding Nine Billion People Sustainably: Conserving Land and Water through Shifting Diets and Changes in Technologies, Environmental Science \& Technology, 48(8): 44444451 .

Strzepek, K., \& Boehlert, B. (2010). Competition for water for the food system. Philosophical Transactions of the Royal Society of London B: Biological Sciences, 365(1554), 2927-2940.

Tilman, D., \& Clark, M. (2014). Global diets link environmental sustainability and human health. Nature, 515(7528), 518-522.

Tilman, D., \& Clark, M. (2015). Food, Agriculture \& the environment: Can we feed the world \& save the Earth?. Daedalus, 144(4), 8-23.

Troell, M., Naylor, R. L., Metian, M., Beveridge, M., Tyedmers, P. H., Folke, C., ... \& Gren, Å. (2014). Does aquaculture add resilience to the global food system? Proceedings of the National Academy of Sciences, 111(37), 13257-13263.

Tscharntke, T., Clough, Y., Wanger, T. C., Jackson, L., Motzke, I., Perfecto, I., ... \& Whitbread, A. (2012). Global food security, biodiversity conservation and the future of agricultural intensification. Biological conservation, 151(1), 53-59.

United Nations, Department of Economic and Social Affairs, Population Division (2017). World Population Prospects: The 2017 Revision, custom data acquired via website.

Valin, H., Sands, R. D., van der Mensbrugghe, D., Nelson, G. C., Ahammad, H., Blanc, E., ... \& Heyhoe, E. (2014). The future of food demand: understanding differences in global economic models. Agricultural Economics, 45(1), 51-67.

Vörösmarty, C. J., Green, P., Salisbury, J., \& Lammers, R. B. (2000). Global water resources: vulnerability from climate change and population growth. Science, 289(5477), 284-288. 
Wada, Y., \& Bierkens, M. F. (2014). Sustainability of global water use: past reconstruction and future projections. Environmental Research Letters, 9(10), 104003.

Welcomme, R.L. (2011) An overview of global catch statistics for inland fish. ICES Journal of Marine Science: doi:10.1093/icesjms/fsr035.

Westhoek, H., Lesschen, J. P., Rood, T., Wagner, S., De Marco, A., Murphy-Bokern, D., ... \& Oenema, O. (2014). Food choices, health and environment: effects of cutting Europe's meat and dairy intake. Global Environmental Change, 26, 196-205.

Westhoek, H., Rood, T., van den Berg, M., Janse, J., Nijdam, D., Reudink, M., ... \& Woltjer, G. B. (2011). The protein puzzle: the consumption and production of meat, dairy and fish in the European Union (No. 500166001). Netherlands Environmental Assessment Agency.

Wolfenson, K. D. M. (2013). Coping with the food and agriculture challenge: smallholders' agenda. Food and Agriculture Organisation of the United Nations, Rome.

Yu, Y., Feng, K., Hubacek, K., \& Sun, L. (2016). Global implications of china's future food consumption. Journal of Industrial Ecology, 20(3), 593-602.

Zhang, C., Postma, J. A., York, L. M., \& Lynch, J. P. (2014). Root foraging elicits niche complementarity-dependent yield advantage in the ancient 'three sisters'(maize/bean/squash) polyculture. Annals of botany, 114(8), 1719-1733. 
Figure 1. Supply of dietary fish and meat in 2013 by continent as a fraction of total animal protein

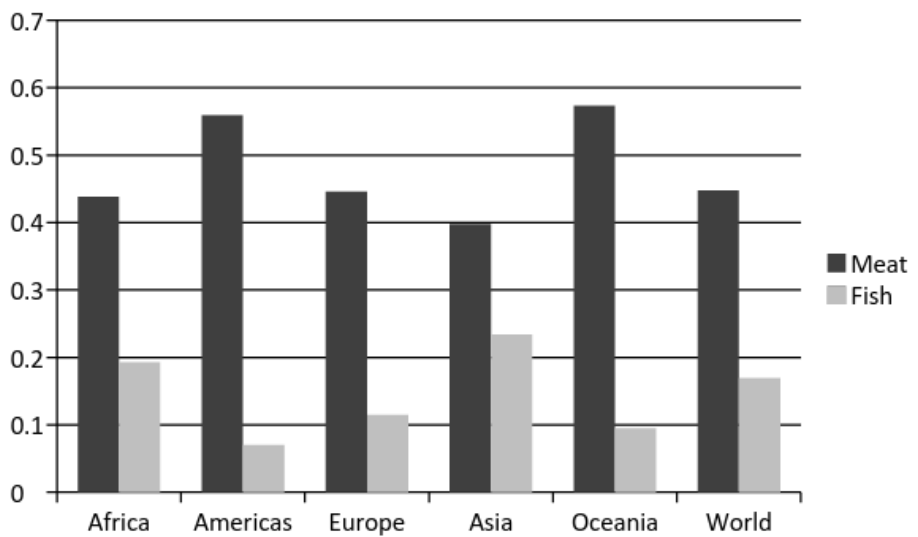

Source: The authors based on data from FAO (2015).

878 Note: The fractions provided by meat plus fish do not sum to total animal protein, which also 879 includes dairy and other products.

880

881

882

883

884

885

886

887

888

889

890

891

892

893

894

895

896

897 
Figure 2. World Fish Capture and Aquaculture 1950-2013

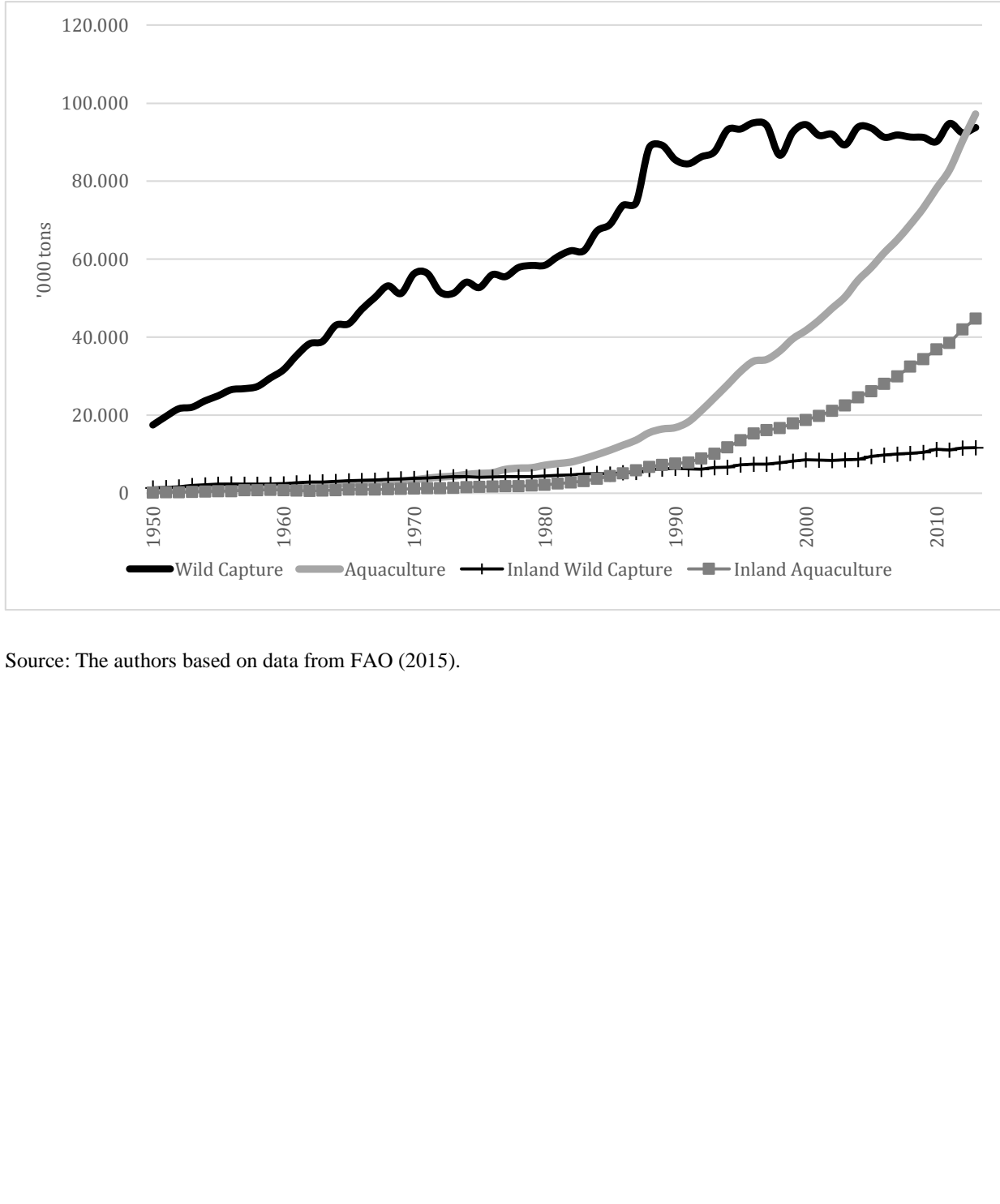


Figure 3. Difference in Costs of Each Scenario Relative to the Baseline (S0) at Gradual Substitutions of 930 Fish Protein

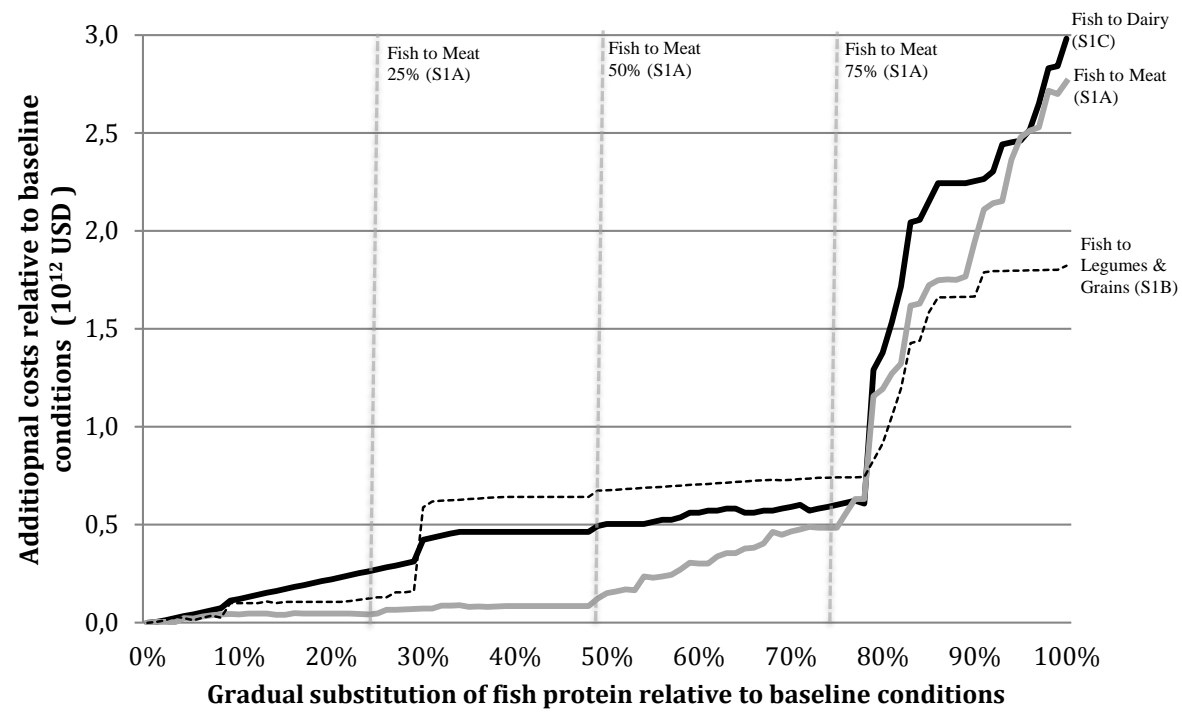

Source: Model results. 
Table 1: Design of Scenarios

\begin{tabular}{|l|l|}
\hline Scenario & Assumptions \\
\hline S0 Baseline 2007 & \\
\hline $\begin{array}{l}\text { S1A Substitution of fish } \\
\text { by livestock }\end{array}$ & $\begin{array}{l}\text { * Intermediate and final demand for fish and processed fish set to zero } \\
\text { * Intermediate and final demand for livestock and processed meat increased } \\
\text { to compensate }\end{array}$ \\
$\begin{array}{l}\text { Including intermediate } \\
\text { substitutions of 25\%, } 50 \%, \\
\text { 75\% of fish by livestock }\end{array}$ & $\begin{array}{l}\text { * Suitable cropland area (unmanaged) increase in cropland endowments } \\
\text { * Relaxation of livestock, fish and food industry sectors capital constraints }\end{array}$ \\
\hline $\begin{array}{l}\text { S1B Substitution of fish } \\
\text { by legumes and grains }\end{array}$ & $\begin{array}{l}\text { * Intermediate and final demand for fish and processed fish set to zero } \\
\text { * Intermediate and final demand for grains, legumes and vegetables (fresh } \\
\text { and processed) increased to compensate } \\
\text { * Relaxation of livestock, fish and food industry sectors capital constraints }\end{array}$ \\
\hline $\begin{array}{l}\text { S1C Substitution of fish } \\
\text { by dairy products }\end{array}$ & $\begin{array}{l}\text { * Intermediate and final demand for fish and processed fish set to zero } \\
\text { * Intermediate and final demand for dairy sources (raw milk and dairy } \\
\text { products) increased to compensate } \\
\text { * Relaxation of livestock, fish and food industry sectors capital constraints }\end{array}$ \\
\hline $\begin{array}{l}\text { S2 Substitution of } \\
\text { livestock by fish }\end{array}$ & $\begin{array}{l}\text { * Intermediate and final demand for livestock and processed meat set to zero } \\
\text { * Intermediate and final demand for fish and processed fish increased to } \\
\text { compensate } \\
\text { * Relaxation of livestock, fish and food industry sectors capital constraints }\end{array}$ \\
\hline
\end{tabular}


978 
Table 2: Output from the Livestock, Processed Meat and Grain Sectors Under the Fish to Meat scenarios (S1A), the Fish to Legumes Scenario (S1B), and the Fish to Dairy Scenario (S1C), and Percentage Change Relative to the Baseline Scenario (S0)

\begin{tabular}{|c|c|c|c|c|c|c|c|c|c|c|c|c|}
\hline \multirow{4}{*}{ Selected sectors } & \multicolumn{8}{|c|}{ Fish to Meat } & \multicolumn{2}{|c|}{$\begin{array}{c}\text { Fish to Legumes and } \\
\text { Grains }\end{array}$} & \multicolumn{2}{|c|}{ Fish to Dairy } \\
\hline & \multicolumn{8}{|c|}{ Scenarios in S1A } & \multirow{2}{*}{\multicolumn{2}{|c|}{ Scenario S1B }} & \multirow{2}{*}{\multicolumn{2}{|c|}{ Scenario S1C }} \\
\hline & \multicolumn{2}{|c|}{$25 \%$} & \multicolumn{2}{|c|}{$\mathbf{5 0 \%}$} & \multicolumn{2}{|c|}{$75 \%$} & \multicolumn{2}{|c|}{$100 \%$} & & & & \\
\hline & $10^{9}$ USD & $\%$ change & $10^{9}$ USD & $\%$ change & $10^{9}$ USD & $\%$ change & $10^{9}$ USD & $\%$ change & $10^{9}$ USD & $\%$ change & $10^{9}$ USD & $\%$ change \\
\hline Livestock & 1,151 & 20 & 1,242 & 29 & 1,307 & 36 & 1,332 & 39 & 1,212 & 26 & 1,211 & 26 \\
\hline Processed Meat & 1,045 & 34 & 1,164 & 50 & 1,319 & 69 & 1,357 & 75 & 901 & 16 & 1,188 & 53 \\
\hline Grains & 814 & 5 & 812 & 5 & 825 & 6 & 852 & 10 & 838 & 8 & 812 & 5 \\
\hline
\end{tabular}

Source: Model results. Tables S9 and S10 in the SI show the regional breakdown for these figures. 
Table 3: Factor Use under the Fish to Meat Scenarios (S1A), Fish to Legumes and Grains (S1B), and Fish to Dairy (S1C), and Percentage Change Relative to the Baseline Scenario (S0)

\begin{tabular}{|c|c|c|c|c|c|c|c|}
\hline \multirow{2}{*}{\multicolumn{2}{|c|}{ Scenarios }} & \multicolumn{2}{|c|}{ Water } & \multicolumn{2}{|c|}{ Pasture Land } & \multicolumn{2}{|c|}{ Cropland } \\
\hline & & $\mathbf{k m}^{3}$ & $\%$ & $10^{6}$ ha & $\%$ & $10^{6} \mathrm{ha}$ & $\%$ \\
\hline \multirow{4}{*}{$\begin{array}{l}\text { Fish to Meat } \\
\text { S1A }\end{array}$} & $25 \%$ & 3,414 & 6 & 2,655 & 4 & 925 & 3 \\
\hline & $50 \%$ & 3,395 & 6 & 2,868 & 12 & 967 & 8 \\
\hline & $75 \%$ & 3,498 & 9 & 3,098 & 21 & 945 & 5 \\
\hline & $100 \%$ & 3,537 & 10 & 3,302 & 29 & 1,133 & 26 \\
\hline \multicolumn{2}{|c|}{$\begin{array}{l}\text { Fish to Legumes and Grains } \\
\text { S1B }\end{array}$} & 3,697 & 15 & 2,589 & 1 & 1,137 & 26 \\
\hline \multicolumn{2}{|c|}{$\begin{array}{l}\text { Fish to Dairy Products } \\
\text { S1C }\end{array}$} & 3,620 & 13 & 3,201 & 25 & 1,162 & 29 \\
\hline
\end{tabular}

Source: Model results. 
Table 4: Percentage Change in Prices of Agricultural and Food Products under All the Scenarios Relative to the Baseline Scenario (S0).

\begin{tabular}{|l|rrr|r|r|r|}
\hline \multicolumn{1}{|c|}{ Sector } & \multicolumn{4}{c|}{$\begin{array}{c}\text { Fish to meat } \\
\text { S1A }\end{array}$} & $\begin{array}{c}\text { Fish to } \\
\text { legumes and } \\
\text { grains }\end{array}$ & $\begin{array}{c}\text { Fish to } \\
\text { dairy }\end{array}$ \\
\cline { 2 - 4 } Raw milk & $\mathbf{2 5 \%}$ & $\mathbf{5 0 \%}$ & $\mathbf{7 5 \%}$ & $\mathbf{1 0 0 \%}$ & S1B & S1C \\
Processed meat & 0 & 3 & 14 & 88 & 7 & 134 \\
Livestock (bovine, sheep, goat) & 0 & 0 & 9 & 82 & 0 & 25 \\
Other Animal Products & 0 & 5 & 18 & 72 & 6 & 68 \\
Dairy & 0 & 3 & 13 & 69 & 7 & 76 \\
Wheat & 0 & 1 & 4 & 25 & 4 & 40 \\
Cereal Grains & 0 & 0 & 3 & 10 & 9 & 6 \\
Paddy and Processed Rice & 0 & 0 & 2 & 9 & 8 & 9 \\
Crops & 0 & 0 & 5 & 8 & 18 & 6 \\
Textiles & 0 & 0 & 1 & 8 & 7 & 3 \\
All other sectors & 0 & 0 & 3 & 0 & 1 & 12 \\
\cline { 1 - 3 } & $<1$ & $<1$ & $<1$ & $<5$ & $<6$ & $<4$ \\
\hline
\end{tabular}

Note: Sectors are identified in Table S3 in the SI.

Source: Model results, in declining order of price increase. 